\title{
The impact of social and cultural capital on the success of language exams
}

\author{
ZITA SOMFALVI*
}

University of Debrecen, Doctoral Program on Educational Sciences, Debrecen, Hungary

\section{THEMATIC ARTICLE}

Published online: June 19, 2020

(C) The Author(s) 2020

\section{ABSTRACT}

The problem of not having a language exam by the end of the university years affects thousands of students in Hungary. The literature reveals that this area is less researched, but there are a number of factors that I found important to examine. I did my research in the East Hungarian region. The reason for this is that many studies in this area have a higher rate of unsuccessful language learners than the rest of the country. I used online survey method in the form of a questionnaire, which consisted mostly of closed questions (alternative, selective and scale). My questions were focused on topics such as socioeconomic status, school life, language biography, cultural capital, language-specific social capital, language-learning type, affective characteristics, language pedagogy, drop-out and language learning attitudes. In this present study I highlight the effect of social and cultural effect on the success of language learning. During the query I used snowball method and address list query. As finding the target people proved to be very difficult, the number of elements is not significant $(N=202)$.

\section{KEYWORDS}

lack of language exam, unsuccessful language learning, language skills

\section{INTRODUCTION}

Foreign language teaching has always been in the centre of interest in Hungary and it also plays a key role in the education system. It has significance in the acquisition of a university degree, in

\footnotetext{
*Corresponding author. E-mail: z.somfalvi@gmail.com
} 
labour market opportunities and in almost all aspects of intellectual life. Although many studies have already examined the conditions of language teaching and learning, their processes and results (including Csapó, 2001; Fekete, Major, \& Nikolov, 1999; Józsa \& Nikolov, 2005), we still cannot say we have enough knowledge of what is happening in foreign language lessons. However, the degree to which students like the learnt foreign language is likely to affect their learning outcomes. Diversity can be seen in the field of development in which linguistic and non-linguistic factors also can play a role. However the question may emerge how we can measure foreign language skills. Many criteria has been used, including testing, imitating sentences, checking grammar, listening, reading and speaking skills (Gardner, 2001), but some criteria are doubtful if we take into consideration that the main aim of language learning is to improve communication. Besides it is also a question how we can measure those non-linguistic factors which probably influence the language learning process. According to studies examining the effect of personality there is no convincing methodology for measuring characteristics.

In Hungary, a number of students are not able to acquire the required language exam by the end of the university years and it is a very actual problem in our education system, so in this study I make an attempt to reveal the social and cultural background of this problem. I made my research in eastern Hungary, because in this area there are more unsuccessful language learners (Nikolov, 2008).

\section{METHODS}

This study contains the analysis of my database, which has a total of 202. I have studied those at the University of Nyíregyháza and the University of Debrecen who finished higher education but have not obtained the degree due to lack of a language exam. I used online questionnaire in which former students had to answer to closed questions (alternative, selective and scale). In my study I examine the factors of unsuccessful language learning. My research is relevant from the point of view of education, including public education and higher education, as language learning is a long process that is rooted in public education and affects the results achieved in higher education. I assume that social status and cultural capital have a significant impact on the language exam. Presumably, the proportion of those who are less well-off and those with less cultural capital is less successful in the language examinations. Consequently, I assume that there will be a higher proportion of those who have obtained their language exam with the help of a Degree Program. In addition, I also assume that there is a higher proportion of those with a disadvantaged social background and those with less cultural capital who have a lack of motivation for language learning or who explain their previous language failure with poor language skills.

\section{RESULTS}

First, I present the variables involved in the analysis and the qualified variables formed from them. The social situation was measured by two indicators (Table 1):

So most of the respondents have their own flat or house, computer, Internet access, half have a car, smartphone, etc.

Using the items listed above, I constructed a Z-score index (standardized the variables involved and then averaged them) and used this to divide the participants into four quartiles: Q1 is the least wealthy and Q4 is the wealthiest group. 
Table 1. The social situation of the participants

\begin{tabular}{lrr}
\hline & Own & $\begin{array}{r}\text { Not } \\
\text { own }\end{array}$ \\
\hline Own house or flat & $8 \%$ & $92 \%$ \\
Smart phone & $54 \%$ & $46 \%$ \\
One car & $49 \%$ & $51 \%$ \\
Two or more cars & $73 \%$ & $27 \%$ \\
Weekend house & $98 \%$ & $2 \%$ \\
Dishwasher & $67 \%$ & $33 \%$ \\
Drier & $92 \%$ & $8 \%$ \\
Air conditioner & $78 \%$ & $22 \%$ \\
Computer & $27 \%$ & $73 \%$ \\
Internet access & $33 \%$ & $67 \%$ \\
\hline
\end{tabular}

As for the residence we've converted the original variable to a 3-category variable: village, small town and big town. Fourty three percentageof the respondents live in the county seat and in the capital, $40 \%$ in small town and $17 \%$ in village.

We have measured the supply of cultural capital in several ways. On the one hand, we examined the parents' educational level, the language skills of the parents and the cultural consumption of the respondents. Respondents' mothers' educational qualifications are generally higher than fathers'. One third of the respondents' mothers have university degree, $42 \%$ have a high school diploma and one quarter have no school leaving certificate. Fifteen percentage of those surveyed have father with degree, 39\% have a high school diploma, and $46 \%$ are skilled workers. When looking at the highest level of education of a father or mother, it can be seen that $39 \%$ of the respondents have at least one parent with a degree and $39 \%$ have a high school diploma. More than a fifth (22\%) of the sample are skilled workers. That is, the vast majority of respondents (61\%) are first-generation 'intellectuals' (or rather graduates) when they graduate. It can also be concluded from the above that the parents' knowledge of the language is very low. Sixty three percentage of mothers and $73 \%$ of fathers have no knowledge of any languages. Fifteen percentage of mothers and 5\% of fathers speak a foreign language at least intermediate level. According to Csapó (2001) it can be observed that the mother's level of education improves performance. The influence of mother's education is most evident in reading tests. His research has shown that parents' education has a positive effect on the child's language learning.

The cultural consumption level of respondents is surprisingly low compared to studying in higher education. $61 \%$ of them never read literature, but only three-quarters of them read entertainment literature (most of them rarely). Twenty six percentage of them never read professional literature, and 39\% read it rarely. Almost three-quarters of the respondents never or only once a year visit a theatre.

The indicators measuring cultural consumption can be reduced to one main component. The retained information share is $51 \%$. Communalities (that is, how strong each component is in the main component) are (Table 2):

The values of the principal component were projected to a 5-point scale with an average of 2.1 (the hypothetical mean is three, which is considered rather low). Our explained variable is whether the respondent has a language exam, and if so, what level. Seventy three percentage of 
Table 2. Communalities in the component analysis

\begin{tabular}{lr}
\hline Regularity of reading literature & 0.751 \\
Regularity of reading professional & 0.818 \\
$\quad$ literature & \\
Regularity of reading entertaining & 0.721 \\
$\quad$ literature & \\
Regularity of going to theatre & 0.594 \\
Regularity of going to library & 0.700 \\
\hline
\end{tabular}

the sample does not have a language exam, $2 \%$ have only a B1 oral or written exam, $4 \%$ have a complex B1. Nine percentage of the students have completed the oral or written examinations on $\mathrm{B} 2$ level, $12 \%$ have passed the complex exam. Two percentage have a $\mathrm{C} 1$ language exam. Slightly merging the original variable (if only written or spoken at a given level combined with the complex) results in $72.5 \%$ having no language exam, $5.5 \% \mathrm{~B} 1,20 \% \mathrm{~B} 2$ and $2 \%$ for $\mathrm{C} 1$.

Thus, above we have learnt the basic distributions of the explanatory variables and the explained variable used in the hypothesis. Cross-tabs test the validity of our assumptions: we test the relationship of variables with a significance test, if significance $<0.05$ then we assume some effect between the explanatory and the explained variable (Table 3 ).

The cross table does not indicate a significant difference, so the financial situation does not seem to have an impact on whether the respondent has a language exam or not. Virtually all wealth groups have the same proportion of those who do not have or have some level of language proficiency (Table 4).

The same is true with the type of place of residence: basically it does not matter what type of place you live, it does not affect whether you have a language exam or not, and if so, what level (Table 5).

Although the crosstab is significant, there does not seem to be a tendency for parents to be educated and have a language exam. While $80 \%$ of skilled parents do not have a language exam, only $65 \%$ of those with a high school diploma do not have a language proficiency certificate, while graduate parents again have a high level of $78 \%$.

Parents' language skills and level are also not significantly related to whether the respondent has a language exam or not.

Since our cultural consumption variable is a high-level variable, we examine the relationship between the variables by one-way analysis of variance rather than by cross-tabulation. The F-test is used, but the significance threshold is still 0.05 (Table 6).

Table 3. Language exam regarding financial situation

\begin{tabular}{lccccc}
\hline & \multicolumn{5}{c}{ Language exam } \\
\cline { 2 - 6 } Financial categories & No exam & B1 & B2 & C1 & All \\
\hline Q1 & 71.4 & 6.1 & 20.4 & 2.0 & 100 \\
Q2 & 72.5 & 2.0 & 23.5 & 2.0 & 100 \\
Q3 & 70.6 & 11.8 & 17.6 & & 100 \\
Q4 & 75.5 & 2.0 & 18.4 & 4.1 & 100 \\
All & 72.5 & 5.5 & 20.0 & 2.0 & 100 \\
\hline
\end{tabular}

Chi2 $=8.607 ; P=0.474$. 
Table 4. Language exam regarding the type of place of residence

\begin{tabular}{lccccc}
\hline & \multicolumn{5}{c}{ Language exam } \\
\cline { 2 - 6 } Residence & No exam & B1 & B2 & C1 & All \\
\hline Village & 70.6 & 5.9 & 20.6 & 2.9 & 100 \\
Small town & 74.4 & 6.4 & 16.7 & 2.6 & 100 \\
Big town & 70.6 & 4.7 & 23.5 & 1.2 & 100 \\
All & 72.1 & 5.6 & 20.3 & 2.0 & 100 \\
\hline
\end{tabular}

Chi2 $=1.810 ; P=0.936$.

Table 5. Language exam regarding the qualification of the parents

\begin{tabular}{lccccc}
\hline & \multicolumn{5}{c}{ Language exam } \\
\cline { 2 - 6 } Qualification of the parents & No exam & B1 & B2 & C1 & All \\
\hline Primary school & $50.00 \%$ & $33.30 \%$ & $16.70 \%$ & & $100 \%$ \\
Skilled worker & $79.50 \%$ & & $17.90 \%$ & $2.60 \%$ & $100 \%$ \\
GCSE & $65.40 \%$ & $5.10 \%$ & $29.50 \%$ & & $100 \%$ \\
Degree & $77.90 \%$ & $6.50 \%$ & $11.70 \%$ & $3.90 \%$ & $100 \%$ \\
All & $72.50 \%$ & $5.50 \%$ & $20.0 \%$ & $2.00 \%$ & $100 \%$ \\
\hline
\end{tabular}

Chi2 $=21.704 ; P=0.010$.

Table 6. Language exam and cultural consumption

\begin{tabular}{lc}
\hline Language exam & $\begin{array}{c}\text { Cultural } \\
\text { consumption }\end{array}$ \\
\hline No exam & 2.0426 \\
B1 & 2.5180 \\
B2 & 2.2847 \\
C1 & 2.8470 \\
All & 2.1395 \\
\hline
\end{tabular}

$F=3.807 ; P=0.011$.

The average component of cultural consumption is 2.0 for those who do not have a language exam, 2.5 for a basic language exam, 2.3 for an intermediate level and 2.8 for an advanced language exam. The difference between the means is significant. The difference between the categories is not linear, but it is clear that those who have a language exam have a higher cultural consumption index.

All in all, it can be seen that those variables showing social status and cultural capital do not show a meaningful relationship with the existence of the language exam, which is primarily based on parental status. However, the personal cultural capital (cultural consumption) of the respondents is yes, in the direction we assumed.

Fourty six percentage of the participants in the survey considered language skills very important, $49 \%$ considered 'fairly' important. Only 6\% said that language skills were only a little important. The financial situation and the education of the parents have no influence on the perception of the importance of language skills. However, the place of residence is yes: the more urbanized a person lives, the more important he or she considers this competence. Parents' 
language skills also have a significant impact: the higher the parents' language is spoken, the more important it is to their child. Finally, we can see significant differences in the indicator measuring cultural consumption, but the results are not tendentious, and the results are difficult to interpret. In any case, it can be seen that status and cultural capital are less influenced by language and family patterns.

We assumed that lower cultural capital, a more disadvantaged social situation is associated with a higher lack of motivation and a poorer language perception. First, let's examine motivation. Motivation was measured on a 5-point scale. Five percentage of the respondents strongly agreed that they had no motivation to learn a language, while $23 \%$ were more likely to agree. Almost half of the sample expressed an intermediate position. The average is 2.98 , slightly below the arithmetic mean (3.0): participants are thus moderately motivated. I test the hypothesis by one-way analysis of variance, using the $\mathrm{F}$ test to determine significant differences $(P<0.05$ threshold).

Neither the financial situation, the settlement type of the place of residence nor the education of the parents has a significant effect on the motivation level related to language learning. At the same time, parents' language skills have an effect on their motivation: the higher their parents' knowledge of a foreign language, the higher their level of motivation (i.e. the lower their motivation deficit).

Considering both cultural consumption and motivation as high variables, correlation can be expected whether or not there is a relationship between the two indicators. The correlation coefficient is $r=-2.232(P=0.002)$. The relationship is significant, but weak and reverse: the higher one's cultural consumption, the lower his or her motivational deficit.

Twenty two percentage said they had a very poor language, and another $33 \%$ said it was more true. The proportion of those who tend not to or do not think so is $20 \%$. The average of the five-point scale is 3.5 - that is, most of those who feel a lack of language.

The place of residence or the language skills of the parents have no influence on how one thinks about one's own language. On the other hand, the financial situation and the educational level of the parents show a significant effect: in essence, the more favourable the status, the more one thinks that one has a poor sense of language. The correlation between cultural consumption and perception of language is not significant $(P=0.081)$.

The perception of the importance of language skills depends rather on the perception of the possibility of use. This can be seen from the linguistic patterns of the place of residence and the parents. The latter pattern (socialization medium) also influences motivation: if one sees the value of language skills at home, he or she is more motivated to learn. 'Poor language perception' as an explanation for failed language learning, on the other hand, has a counter-hypothesis to the social situation; This is probably due to cognitive dissonance, meaning that these students know that they should already have a language exam by their status (as most of their university peers already have it, or a successful language exam is a mandatory requirement), and some lack of explanation can resolve it.

Skehan (1991) regards language perception as a trait that influences the success of language learning, regardless of prior language learning experiences and the different foreign language abilities of individuals, with which many researchers agree (Carroll, 1990; Otto, 2003; Parry \& Child, 1990). According to Skehan (1991), language perception can be said to be constant and difficult to modify.

Ganschow and Sparks (1991) have been researching the difficulty of learning a foreign language since the eighties. In their view, the main reason for this is that the learner is unable to process the phonological aspects of the foreign language and to master its orthographic-phonetic 
features. This is called a language coding deficit. According to their theory, mother tongue skills are the basis for learning foreign languages, and difficulty with any one of the language components has a negative impact on both mother tongue and foreign language learning.

\section{CONCLUSION}

As a result of my research, it can be stated that those variables that indicate social status and cultural capital do not show a meaningful connection with the existence of the language exam, which are primarily based on parental status. However, the cultural consumption of the personal cultural capital of the respondents is. In unsuccessful language learning other factors may play important roles like childhood residence, type of secondary school, learning strategies, or the motivation of the learner, which factors are going to be studied in the future.

Ethics: The study procedures were carried out in accordance with the Declaration of Helsinki. The Institutional Review Board of the Institute of Educational and Cultural Sciences (University of Debrecen) approved the study.

Funding sources: No financial support was received for this study.

Authors' contribution: All authors take responsibility for the integrity of the data and the accuracy of the data analysis.

Conflict of interest: The authors declare no conflict of interest.

\section{ACKNOWLEDGEMENTS}

No additional acknowledgement.

\section{ABOUT THE AUTHOR}

Zita Somfalvi is a teacher of English language and methodology at the University of Nyíregyháza, faculty of English language and culture. She is working on her PhD thesis in the Doctoral School of Human Sciences at the University of Debrecen, in the topic of unsuccessful language learning and drop out.

\section{REFERENCES}

Carroll, J. B. (1990). Cognitive abilities in foreign language aptitude: Then and now.

Csapó, B. (2001). A kognitív képességek szerepe a tudás szervezésében. In Zoltán, Báthory, \&és Falus, Iván (szerk.), Tanulmányok a neveléstudomóny kóréból (pp. 270-293). Osiris Kiadó. 
Fekete, H., Major, É., \& Nikolov, M. (szerk.) (1999). English language education in Hungary: A baseline study. Budapest: The British Council.

Ganschow, L., \& Sparks, R. L. (1991). Foreign language learning differences: Affective or native language aptitude differences? The Modern Language Journal, 75(1).

Gardner, R. C. (2001). Language learning motivation: The student, the teacher, and the resercher. Texas Papers in Foreign Language Educations, 6(1), 1-18.

Józsa, K., \& Nikolov, M. (2005). Az angol és német nyelvi készségek fejlettségét befolyásoló tényezők. Magyar Pedagógia, 3, 307-337.

Otto, F. (2003). Restarting automata and their relations to the Chomsky hierarchy. In Developments in language theory (pp. 55-74).

Parry, T. S., \& Child, J. R. (1990). Preliminary investigation of the relationship between VORD, MLAT and language proficiency. Spons Agency.

Skehan, P. (1991). Individual differences in second language learning, In Studies in second language acquisition: Vol. 13, 2 (pp. 275-298).

Open Access statement. This is an open-access article distributed under the terms of the Creative Commons Attribution 4.0 International License (https://creativecommons.org/licenses/by/4.0/), which permits unrestricted use, distribution, and reproduction in any medium, provided the original author and source are credited, a link to the CC License is provided, and changes - if any - are indicated. (SID_1) 